\title{
PENGARUH GAYA KEPEMIMPINAN KEPALA SEKOLAH DAN KECERDASAN SPIRITUAL GURU TERHADAP KOMITMEN KERJA GURU DI SEKOLAH DASAR YANG BERBASIS ISLAM DI KECAMATAN JATISAMPURNA-BEKASI
}

\author{
Wahyu Yulianto \\ STKIP Kusuma Negara Jakarta, Indonesia \\ Email: wahyuyulianto24@gmail.com
}

Informasi Artikel
Kata kunci:
Gaya kepemimpinan
kepala sekolah,
Kecerdasan spiritual guru,
Analisis jalur,
Sekolah Dasar yang
berbasis Islam

Diterima: 23-09-2020

Disetujui: 15-10-2020

Dipubikasikan: 26-10-2020

\section{Abstrak}

Penelitian ini bertujuan untuk mengetahui bagaimana pengaruh gaya kepemimpinan kepala sekolah dan kecerdasan spiritual guru terhadap komitmen kerja guru di sekolah dasar yang berbasis Islam di kecamatan Jatisampurna-Bekasi. Variabel-variabel yang dianalisis adalah gaya kepemimpinan kepala sekolah dan kecerdasan spiritual sebagai variabel terikat, dan komitmen kerja sebagai variabel terikat. Penelitian ini menggunakan metode survei kasual dengan populasi terdiri dari 127 Guru Sekolah Dasar Islam di Kecamatan Jatisampurna, Bekasi. Yang tersebar di 5 Sekolah Islam Kecamatan Jatisampurna, Bekasi.Teknik pengambilan sampel menggunakan Proportional Random Sampling dengan menggunakan rumus Slovin maka, didapatkan sampel penelitian sebanyak 96 guru. Hasil penelitian menunjukkan bahwa; pertama, terdapat pengaruh positif antara gaya kepemimpinan kepala sekolah terhadap komitmen kerja guru dengan garis regresi $\mathrm{X}_{3}=5,153+$ $0,718 \mathrm{X}_{1}$, koefisien korelasi $\mathrm{r}_{3.1}=0.641$ dengan koefisien determinasi 0.411 . Hasil ini berarti 41,10\% variansi variabel komitmen kerja guru ditentukan oleh variabel Gaya kepemimpinan kepala sekolah. Kedua, terdapat pengaruh langsung positif antara kecerdasan spiritual guru terhadap komitmen kerja guru, dengan persamaan garis regresi $\mathrm{X}_{3}=11,904+0,717 \mathrm{X}_{2}$, koefisien korelasi 0,624 dengan koefisien determinasi 0, 390, hal ini berarti 39,00\% variansi variabel komitmen kerja guru ditentukan oleh kecerdasan spiritual guru. Ketiga, terdapat pengaruh langsung antara Gaya kepemimpinan kepala sekolah terhadap kecerdasan spiritual guru dengan persamaan regresi $\mathrm{X}_{2}=33,754+$ $0,535 \mathrm{X}_{1}$, koefisien korelasi 0,548 dengan koefisien determinasi 0,301 , hal ini berarti bahwa 30,10\% variansi variabel kecerdasan spiritual guru ditentukan oleh gaya kepemimpinan kepala sekolah.

\section{PENDAHULUAN}

Dalam dunia kerja komitmen menjadi sebuah isu yang sangat penting terutama berkaitan dengan kinerja perusahaan ataupun organisasi dimana individu bekerja. Kajian tentang komitmen kerja menjadi bahan 
persoalan krusial yang mendasar bagi berjalannya roda organisasi maupun perusahaan agar berjalan dengan efektif dan efisisen.

Individu yang tidak memiliki komitmen kerja cenderung memiliki sikap tidak terlalu peduli dengan kemajuan organisasi dan apa yang akan dicapai organisasi, karena dibenak mereka hanya memandang mereka bekerja berdasarkan kepentingan pribadi tanpa bekerja maksimal dalam dunia kerja sehingga berimbas pada kemungkinan individu tersebut akan dengan mudah keluar dari perusahaan dan menganggap perusahaan atau organisasi sebelumnya sebagai batu loncatan untuk ia mendapatkan pekerjaan yang lebih baik diluar sana. Maka diperlukan komitmen kerja yang tinggi dalam setiap masing-masing individu di dunia kerja saat ini.

Komitmen guru adalah keberpihakan guru terhadap perannya, yang tinggi atau rendahnya ditandai dengaan dedikasi, tanggung jawab tugas, loyalitas dan kepercayaan serta dapat menyesuaikan diri dengan perkembangan ilmu pengetahuan (Mutiara SIbarani Panggabean, 2002.)

Kinerja seorang guru dapat dipengaruhi oleh berbagai hal termasuk diantaranya gaya kepemimpinan kepala sekolah dalam lingkungan kerja sekolah. Seorang kepala sekolah yang memiliki gaya kepemimpinan yang demokratis mampu memberikan ruang yang besar bagi guru dalam menelurkan gagasan-gagasan yang dimilikinya, kemudian berdampak pada implementasi ide guru tersebut yang pada akhirnya sang guru merasa dihargai dan merasa memiliki andil besar dalam proses kemajuan lembaga pendidikan dimana ia bertugas. sebaliknya dengan gaya kepemimpinan kepala sekolah yang cenderung otokrasi, gaya kepemimpinan ini digambarkan sebagai seorang pemimpin yang menempatkan segala keputusan berada pada diri pemimpin tersebut dan guru atau karyawan hanya sebagai pelaksana keputusan yang sudah digariskan oleh kepala sekolah sebagai pemimpin di sekolah (Veithzal Rivai, \& Deddy Mulyadi,. 2011)

Disisi lain yang mempengaruhi komitmen kerja guru selain karena dipengaruhi oleh faktor ekstern (gaya kepemimpinan kepala sekolah) dapat juga dipengaruhi oleh faktor intern (kecerdasaan spiritual) yag dimiliki oleh setiap guru. Kecerdasan spiritual dalam konteks ini adalah bagaimana guru yang memiliki kecerdasaan spiritual (religiusitas) mampu bekerja dengan ikhlas dan qanaah dalam setiap tanggung jawab yang diembannya. Seseorang yang memiliki kecerdasan spiritual memiliki pandangan bahwa bekerja bagi mereka adalah bagian dari ibadah bagi tiap-tiap individu yang memilki kecerdasan social. Dengan memiliki kecerdasan spiritual seorang guru bekerja bukan hanya menjadikan pekerjaannya sebagai pemenuhan kebutuhan jasmani saja, melainkan bentuk lain dari konsep ibadah.

Dari latar belakang diatas, studi ini bertujuan mengetahui Pengaruh Gaya Kepemimpinan Kepala Sekolah dan Kecerdasan Spiritual Guru terhadap Komitmen Kerja Guru di Sekolah Dasar yang berbasis Islam di kecamatan Jatisampurna Bekasi. 


\section{KAJIAN PUSTAKA}

Menurut bahasa komitmen berasal dari bahasa latin : Commitere, to connect, entrust the state of being obligated or emotionally impelled. Adalah keyakinan yang mengikat (aqad) sedemikian kukuhnya sehingga membelenggu seluruh hati nuraninya dengan kemudian menggerakan perilaku menuju arah tertentu yang diyakininya (I'tiqad ) ( Toto Asmara,2002), sedangkan menurut Daniel Goldman dalam sebuah penelitiannya mengatakan, bahwa orang yang berkomitmen adalah para warga yang perusahaan teladan. Mereka bersedia menempuh perjalanan lebih panjang. Artinya seorang yang memiliki komitmen kerja tinggi mampu menjalani pekerjaannya lebih dari ekspektasi yang diharapkan oleh organisasi. Lebih jauh goldman mengidentifikasikan ciri-ciri orang yang berkomitmen antara lain : (1). Siap berkorban demi pemenuhan sasaran perusahaan yang lebih penting, (2). Merasakan dorongan semangat dalam misi yang lebih besar, (3) Menggunakan nilai-nilai kelompok dalam pengambilan keputusan dan penjabaran pilihan (Toto Tasmara,2002) sama hal nya dengan yang dikatakan oleh Cooper dann Sawwaf menjelaskan komitmen merupakan keterikatan seseorang untuk melakukan atau tidak melakukan kegiatan tertentu sesuai dengan perjanjian (Robert K.Cooper dan Ayman Shawaf. 1999.) Guru sebagai seorang pendidik selain memiliki komitmen terhadap pekerjaannya yakni memberikan pengajaran pada siswa melainkan juga memiliki komitmen lainnya seperti yang dijelaskan oleh Louis yakni sekolah dan pendidikan bermutu ( dalam Ahmad dan Razak, 2007) komitmen kerja guru dipengaruhi oleh faktor internal dan juga faktor eksternal salah satu faktor eksternal dipengaruhi oleh gaya kepemimpinan kepala sekolah Menurut wirawan Gaya kepemimpinann sebagai pola perilaku pemimpin dalam mempengaruhi para pengikutnya (Wirawan. 2002) Tidak jauh dari Wirawan menurut Toha dan Mulyasa (E.Mulyasa. 2009) sehingga dengan begitu gaya kepimipinan akan mempengaruhi sikap dan visi serta orientasi komitmen kerja, gaya kepemimpinan dibagi menjadi 3 gaya gaya otoriter, kendali bebas dan demokrasi (Veithzal Rivai dan Deddy Mulyadi, 2011) ada faktor internal lain yang mampu meningkatkan komitmen kerja guru yakni kecerdasan spiritual Gardner menilai kecerdasan itu sebagai Sebuah kebudayaan yang tercipta dari proses pembelajaran, perilaku, pola kehidupan antarmanusia, dan alam atau lingkungan yang terkristalisasi dalam babit (kebiasan) (Munif Chatib dan Alamsyah Said. 2012) sedangkan menurut Danah Zohar dan Ian Marshall mendefiniskan kecerdasan spiritual adalah : kecerdasan untuk memecahkan persoalan makna dan nilai, yaitu kecerdasan untuk menempatkan perilaku dan hidup dalam konteks makna yang lebih luas dan kaya kecerdasan untuk menilai bahwa tindakan atau jalan hidup seseorang lebih bermakna dibanding yang lain (Danah Zohar dan Ian Marshall. 2001) senada menurut Toto Tasmara sebuah keyakinan yang mampu mengatasi seluruh perasaan yang bersifat jasad, bersifat sementara dan fana. (Toto tasmara 2002) hal ini semakin diperkuat bahwa SQ mampu menunjang komitemen kerja guru menurut Brown \& Seargeant dalam tulisannnya mengatakan bahwa agama merupakan salah satu prediktor bermakna terhadap komitmen organisasi pada organisasi yang berlatar belakang agama. (Brown,D., \& Sargeant,2007) 


\section{METODE}

Bentuk penelitian ini adalah dengan menggunakan metode penelitian kuantitatif. Penelitian kuantitatif adalah penelitian yang digunakan untuk menjawab permasalahan melalui teknik pengukuran yang cermat terhadap variabel-variabel tertentu, sehingga menghasilkan simpulan-simpulan yang digeneralisasikan, lepas dari konteks waktu dan situasi serta jenis data yang dikumpulkan terutama data kuantitatif.( Zainal Arifiin.2012) selanjutunya dalam penelitian yang berjumlah 103 orang guru maka berdasarkan Arikunto (2006) yang menyatakan bahwa jika jumlah populasi lebih dari 100 orang, maka jumlah sampel yang diambil 10\%-30\% dari jumlah populasi yang ada didapatkan data sampel guru sebanyak 51 guru .penyebaran kueisioner ini mengunakan skala likert

Dalam skala likert, responden tidak hanya memilih pernyataan positif, tetapi juga pernyataan negatife. Tiap item dibagi ke dalam lima skala, yaitu sangat sering (ss), sering (s), kadang-kadang (kke), pernah (p), dan sangat tidak pernah (tp). uji validitas dengan menggunakan metode product momen pearson, sedangkan uji realibilitas menggunakan metode Alpha Cronbach dan dilakukan uji coba pada responden. Uji-t digunakan untuk mengetahui apakah variabel bebas (independent) signifikan atau tidak terhadap variabel dependen secara individual untuk setiap variabel.

\section{HASIL DAN PEMBAHASAN}

Data yang akan disajikan dari hasil penelitian ini adalah untuk memberikan gambaran secara umum mengenai penyebaran data yang diperoleh di lapangan. Data yang disajikan berupa data mentah yang di dapatkan oleh peneliti kemudian diolah menggunakan teknik statistik deskripsi. Dalam deskripsi data ini yang disajikan terhadap bentuk distribusi frekuensi, total skor, harga skor rata-rata, simpangan baku, modus, median, skor maksimum dan skor minimum yang disertai histogram. pengujian reliabilitas instrument dalam penelitian ini digunakan rumus Alpha Cronbach, hasil penghitungan terhadap variable-variabel tersebut ditunjuk dalam tabel berikut:

TABEL 1. RELIABILITAS

\begin{tabular}{clcc}
\hline NO & INSTRUMEN VARIABEL & $\mathbf{R}_{\text {hitung }}$ & KETERANGAN \\
\hline $\mathbf{1}$ & Komitmen Kerja Guru $(\mathrm{Y})$ & 0,850 & $\begin{array}{c}\text { Reliabilitas instrument sangat } \\
\text { kuat }\end{array}$ \\
\hline $\mathbf{2}$ & Gaya Kepemimpinan Kepala Sekolah $\left(\mathrm{X}_{1}\right)$ & 0,881 & $\begin{array}{c}\text { Reliabilitas instrument sangat } \\
\text { kuat }\end{array}$ \\
\hline $\mathbf{3}$ & Kecerdasan Spiritual $\left(\mathrm{X}_{2}\right)$ & 0,894 & $\begin{array}{c}\text { Reliabilitas instrument sangat } \\
\text { kuat }\end{array}$ \\
\hline
\end{tabular}

Kemudian dilakukan uji normalitas data Hasil analisis data tentang uji normalitas terhadap uji "Kolmogorov-Smimov Test" (Liliefors) tersebut diatas mengfinformasikan bahwa semua data memiliki distribusi normal. Hasil analisis tersebut dirangkum dalam Tabel dibawah ini : 
Tabel 2 Rangkuman Hasil Uji Normalitas Variabel Penelitian

\begin{tabular}{ccccc}
\hline Variabel & $\mathbf{N}$ & Sig. hitung & $\square$ & Keterangan \\
\hline $\mathrm{X}_{3}$ & 96 & 0,200 & 0,05 & Normal \\
\hline $\mathrm{X}_{1}$ & 96 & 0,200 & 0,05 & Normal \\
\hline $\mathrm{X}_{2}$ & 96 & 0,200 & 0,05 & Normal \\
\hline
\end{tabular}

Dari hasil uji homogenitas terhadap menghitung varians varians $\mathrm{X}_{3}$ atas pengelompokan $\mathrm{X}_{1}$ dan $\mathrm{X}_{2}$ dan $\mathrm{X}_{2}$ atas $\mathrm{X}_{1}$ dapat disimpulkan bahwa kelompok data berasal dari populasi yang homogen. Rangkuman pengujian homogenitas seperti yang tampak pada Tabel 3.

Tabel 3 Rangkuman Hasil Uji Homogenitas Data

\begin{tabular}{cccccc}
\hline No. & Varians & $\begin{array}{c}\text { Sig. } \\
\text { hitung }\end{array}$ & $\square$ & Kesimpulan & Keterangan \\
\hline 1 & $\mathrm{X}_{3}$ atas $\mathrm{X}_{1}$ & 0,242 & 0,05 & Terima $\mathrm{H}_{\circ}$ & Homogen \\
\hline 2 & $\mathrm{X}_{3}$ atas $\mathrm{X}_{2}$ & 0,063 & 0,05 & Terima $\mathrm{H}_{\circ}$ & Homogen \\
\hline 3 & $\mathrm{X}_{2}$ atas $\mathrm{X}_{1}$ & 0,058 & 0,05 & Terima $\mathrm{H}_{\circ}$ & Homogen \\
\hline
\end{tabular}

Dari hasil uji normalitas dan uji homogenitas di atas, telah teruji data berdistribusi normal dan berasal dari populasi yang homogen. Terhadap demikian, pengujian hipotesis dapat dilakukan. Uji linearitas data melihat Sig. Deviation from Linearity. Jika Sig $>0,05$ maka data linear, jika Sig $<0,05$, maka data tidak linear.

Tabel 4. Uji Linearitas $\mathrm{X}_{3}$ atas $\mathrm{X}_{1}$

ANOVATable

\begin{tabular}{|c|c|c|c|c|c|c|c|}
\hline & & & $\begin{array}{l}\text { Sum of } \\
\text { Squares }\end{array}$ & df & $\begin{array}{l}\text { Mean } \\
\text { Square }\end{array}$ & $F$ & Sig. \\
\hline \multirow{5}{*}{$\begin{array}{l}\text { Komitmen Kerja* } \\
\text { Gaya Kepemimpinan } \\
\text { Kepala Sekolah }\end{array}$} & Between & (Combined) & 4214.467 & 29 & 145.326 & 3.170 & .000 \\
\hline & Groups & Linearity & 2975.623 & 1 & 2975.62 & 64.915 & .000 \\
\hline & & $\begin{array}{l}\text { Deviation from } \\
\text { Linearity }\end{array}$ & 1238.844 & 28 & 44.244 & .965 & .527 \\
\hline & Within Group & & 3025.367 & 66 & 45.839 & & \\
\hline & Total & & 7239.833 & 95 & & & \\
\hline
\end{tabular}

Tabel 5. Uji Linearitas $X_{3}$ atas $X_{2}$

\section{ANOVATable}

\begin{tabular}{|c|c|c|c|c|c|c|c|}
\hline & & & $\begin{array}{l}\text { Sum of } \\
\text { Squares }\end{array}$ & df & $\begin{array}{l}\text { Mean } \\
\text { Square }\end{array}$ & $F$ & Sig. \\
\hline \multirow{5}{*}{$\begin{array}{l}\text { Komitmen Kerja }{ }^{*} \\
\text { Kecerdasan Spritual Guru }\end{array}$} & Between & (Combined) & 4226.500 & 30 & 140.883 & 3.039 & .000 \\
\hline & Groups & Linearity & 2821.172 & 1 & 2821.172 & 60.855 & .000 \\
\hline & & $\begin{array}{l}\text { Deviation from } \\
\text { Linearity }\end{array}$ & 1405.328 & 29 & 48.460 & 1.045 & .428 \\
\hline & Within Grou & & 3013.333 & 65 & 46.359 & & \\
\hline & Total & & 7239.833 & 95 & & & \\
\hline
\end{tabular}


Tabel 6. Uji Linearitas $\mathrm{X}_{2}$ atas $\mathrm{X}_{1}$

ANOVATable

\begin{tabular}{|c|c|c|c|c|c|c|c|}
\hline & & & $\begin{array}{l}\text { Sum of } \\
\text { Squares }\end{array}$ & $d f$ & $\begin{array}{l}\text { Mean } \\
\text { Square }\end{array}$ & $F$ & Sig. \\
\hline \multirow{5}{*}{$\begin{array}{l}\text { Kecerdasan Spritual Guru } \\
\text { * Gaya Kepemimpinan } \\
\text { Kepala Sekolah }\end{array}$} & \multirow{3}{*}{$\begin{array}{l}\text { Between } \\
\text { Groups }\end{array}$} & (Combined) & 2831.024 & 29 & 97.622 & 2.421 & .002 \\
\hline & & Linearity & 1651.203 & 1 & 1651.203 & 40.957 & .000 \\
\hline & & $\begin{array}{l}\text { Deviation from } \\
\text { Linearty }\end{array}$ & 1179.821 & 28 & 42.136 & 1.045 & .428 \\
\hline & \multicolumn{2}{|c|}{ Within Groups } & 2660.810 & 66 & 40.315 & & \\
\hline & \multicolumn{2}{|l|}{ Total } & 5491.833 & 95 & & & \\
\hline
\end{tabular}

Hasil analisis data tentang uji linearitas tersebut diatas menginformasikan bahwa semua data memiliki data yang linear karena Sig > 0,05.selanjutnya penulis melakukan uji hipotesis dengan menggunakan rumus regresi dan korelasi Untuk mengetahui koefisien korelasi diatas signifikan atau tidak, digunakan uji t.

Dari hasil analisis regresi diperoleh bahwa Pengaruh antara Gaya Kepemimpinan Kepala Sekolah $\left(\mathrm{X}_{1}\right)$ dan Komitmen Kerja $\left(\mathrm{X}_{3}\right)$ digambarkan terhadap persamaan $\hat{\mathrm{X}}_{3}=5,153+0,718 \mathrm{X}_{1}$. Seperti pada tabel 4 dibawah ini:

Tabel 7. Coeficient

\begin{tabular}{|c|c|c|c|c|c|c|}
\hline \multicolumn{7}{|c|}{ Coefficients $^{\mathrm{a}}$} \\
\hline \multirow[b]{2}{*}{ Model } & & \multicolumn{2}{|c|}{$\begin{array}{l}\text { Unstandardized } \\
\text { Coefficients }\end{array}$} & \multirow{2}{*}{$\begin{array}{c}\begin{array}{c}\text { Standardized } \\
\text { Coefficients }\end{array} \\
\text { Beta }\end{array}$} & \multirow[b]{2}{*}{$t$} & \multirow[b]{2}{*}{ Sig. } \\
\hline & & $B$ & Std. Error & & & \\
\hline 1 & (Constant) & 5.153 & 8.226 & & .626 & .533 \\
\hline & $\begin{array}{l}\text { Gaya Kepemimpinan } \\
\text { Kepala Sekolah }\end{array}$ & .718 & .089 & .641 & 8.099 & .000 \\
\hline
\end{tabular}

a. Dependent Variable: Komitmen Kerja

disimpulkan bahwa korelasi antara Gaya Kepemimpinan Kepala Sekolah dan Komitmen Kerja signifikan dan linear. Adapun kekuatan korelasi antara Gaya Kepemimpinan Kepala Sekolah terhadap Komitmen Kerja ditunjukkan terhadap perhitungan koefisien korelasi dari rumus korelasi Product Moment $\left(\mathrm{r}_{\mathbf{x} 1 \times 3}\right)$, yaitu sebesar 0,641 .

Rangkuman hasil pengujian korelasi seperti tampak pada tabel 5.

Tabel 8. Nilai Koefesien Korelasi (R) dan Koefisien Determinasi (R Square) antara Gaya Kepemimpinan Kepala Sekolah $\left(\mathrm{X}_{1}\right)$ dan Komitmen Kerja $\left(\mathrm{X}_{3}\right)$

Model Summary
\begin{tabular}{|l|r|r|r|r|}
\hline Model & R & R Square & $\begin{array}{c}\text { Adjusted } \\
\text { R Square }\end{array}$ & $\begin{array}{c}\text { Std. Error of } \\
\text { the Estimate }\end{array}$ \\
\hline 1 & $.641^{\mathrm{a}}$ & .411 & .405 & 6.735 \\
\hline
\end{tabular}
a. Predictors: (Constant), Gaya Kepemimpinan Kepala
Sekolah

Dari hasil analisis uji t pada tabel 5, diperoleh $t_{\text {hitung }}$ sebesar 8,099 dan $t_{\text {tabel }}$ sebesar 1,98. Artinya, terdapat Pengaruh yang positif antara variabel Gaya Kepemimpinan Kepala Sekolah dan Komitmen Kerja karena thitung $>$ tabel, yaitu 8,099 > 1,98. Rangkuman hasil pengujian korelasi seperti tampak pada tabel 6 Dari hasil analisis 
regresi diperoleh bahwa Pengaruh antara Kecerdasan Spritual Guru ( $\left.\mathrm{X}_{2}\right)$ dan Komitmen Kerja $\left(\mathrm{X}_{3}\right)$ digambarkan terhadap persamaan $\hat{\mathrm{X}}_{3}=11,904+0,717 \mathrm{X}_{2}$. Seperti pada tabel 6 dibawah ini:

Tabel 9. Coeficient

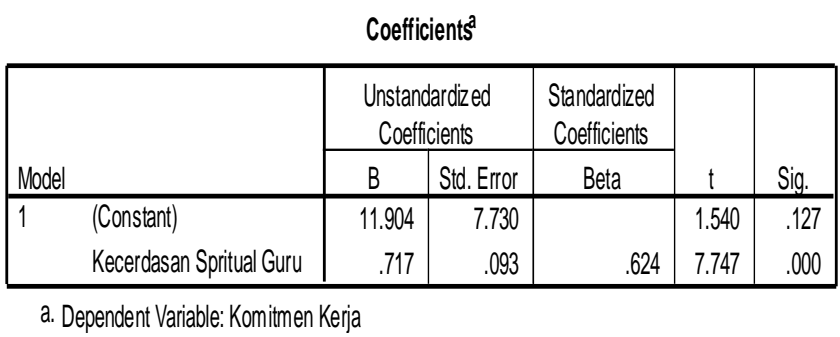

Dari hasil tersebut, disimpulkan bahwa korelasi antara Kecerdasan Spititual dan Komitmen Kerja signifikan dan linear. kekuatan korelasi antara Kecerdasan Spritual Guru terhadap Komitmen Kerja ditunjukkan terhadap perhitungan koefisien korelasi dari rumus korelasi Product Moment $\left(\mathrm{r}_{\mathrm{x} 2 \times 3}\right)$, yaitu sebesar 0,624 . Untuk mengetahui koefisien korelasi diatas signifikan atau tidak, digunakan uji t

Tabel 9. Nilai Koefesien Korelasi (R) dan Koefisien Determinasi (R Square) antara Kecerdasan Spritual Guru ( $\mathrm{X}_{2}$ ) dan Komitmen Kerja $\left(\mathrm{X}_{3}\right)$

\section{Model Summary}

\begin{tabular}{|l|r|r|r|r|}
\hline Model & R & R Square & $\begin{array}{l}\text { Adjusted } \\
\text { R Square }\end{array}$ & $\begin{array}{r}\text { Std. Error of } \\
\text { the Estimate }\end{array}$ \\
\hline 1 & $.624^{2}$ & .390 & .383 & 6.856 \\
\hline
\end{tabular}

a. Predictors: (Constant), Kecerdasan Spritual Guru

Dari hasil analisis uji t pada tabel 5 diperoleh thitung sebesar 7,747 dan tabel sebesar 1,98. Artinya, terdapat Pengaruh yang positif antara variabel Kecerdasan Spritual Guru dan Komitmen Kerja karena $t_{\text {hitung }}>t_{\text {tabel, }}$ yaitu 7,747 > 1,98.kemudian hasil analisis regresi diperoleh bahwa Pengaruh antara Gaya Kepemimpinan Kepala Sekolah $\left(\mathrm{X}_{1}\right)$ dan Kecerdasan Spritual Guru $\left(\mathrm{X}_{3}\right)$ digambarkan terhadap persamaan $\hat{\mathbf{X}}_{2}=33,754+0,535 \mathrm{X}_{1}$. Seperti pada tabel 8 dibawah ini:

Tabel 10. Coeficient

Coefficients $^{\mathrm{a}}$

\begin{tabular}{|c|c|c|c|c|c|c|}
\hline \multirow[b]{2}{*}{ Model } & & \multicolumn{2}{|c|}{$\begin{array}{c}\text { Unstandardized } \\
\text { Coefficients }\end{array}$} & \multirow{2}{*}{$\begin{array}{c}\text { Standardized } \\
\text { Coefficients }\end{array}$} & \multirow[b]{2}{*}{$t$} & \multirow[b]{2}{*}{ Sig. } \\
\hline & & $B$ & Std. Error & & & \\
\hline 1 & (Constant) & 33.754 & 7.807 & & 4.324 & .000 \\
\hline & $\begin{array}{l}\text { Gaya Kepemimpinan } \\
\text { Kepala Sekolah }\end{array}$ & .535 & .084 & .548 & 6.357 & .000 \\
\hline
\end{tabular}

a. Dependent Variable: Kecerdasan Spritual Guru 
Dari hasil tersebut, disimpulkan bahwa korelasi antara Gaya Kepemimpinan Kepala Sekolah dan Kecerdasan Spritual Guru signifikan dan linear. kekuatan korelasi antara Gaya Kepemimpinan Kepala Sekolah terhadap Kecerdasan Spritual Guru ditunjukkan terhadap perhitungan koefisien korelasi dari rumus korelasi Product Moment $\left(\mathrm{r}_{\times 1 \times 2}\right)$, yaitu sebesar 0,548. Untuk mengetahui koefisien korelasi diatas signifikan atau tidak, digunakan uji t. Rangkuman hasil pengujian korelasi seperti tampak pada tabel 9

Tabel 11. Nilai Koefesien Korelasi (R) dan Koefisien Determinasi (R Square) antara Gaya Kepemimpinan Kepala Sekolah $\left(\mathrm{X}_{1}\right)$ dan Kecerdasan Spritual Guru $\left(\mathrm{X}_{3}\right)$

\section{Model Summary}

\begin{tabular}{|l|r|r|r|r|}
\hline Model & \multicolumn{1}{|c|}{ R } & R Square & $\begin{array}{l}\text { Adjusted } \\
\text { R Square }\end{array}$ & $\begin{array}{r}\text { Std. Error of } \\
\text { the Estimate }\end{array}$ \\
\hline 1 & $.548^{\mathrm{a}}$ & .301 & .293 & 6.392 \\
\hline
\end{tabular}

a. Predictors: (Constant), Gaya Kepemimpinan Kepala Sekolah

Dari hasil analisis uji t pada tabel 20, diperoleh thitung sebesar 6,357 dan $t_{\text {tabel }}$ sebesar 1,98. Artinya, terdapat Pengaruh yang positif antara variabel Gaya Kepemimpinan Kepala Sekolah dan Kecerdasan Spritual Guru karena thitung $>t_{\text {tabel, }}$ yaitu $6,357>1,98$.

\section{PEMBAHASAN}

Berdasarkan hasil korelasi antara $X_{1}, X_{2}$ dan $X_{3}$ tersebut di atas didapat $r_{x 1 \times 3}=0,641, r_{x 2 \times 3}=0,624$ dan $\mathrm{r}_{\mathrm{x} 1 \times 2}=0,548$, langkah selanjutnya mencari analisis jalur (path analysis) didapat $\mathrm{p}_{21}=0,55, \mathrm{p}_{31}=0,43$ dan $\mathrm{p}_{32}=$ 0,39 di atas 0,05 yang berarti path analysisnya signifikan.

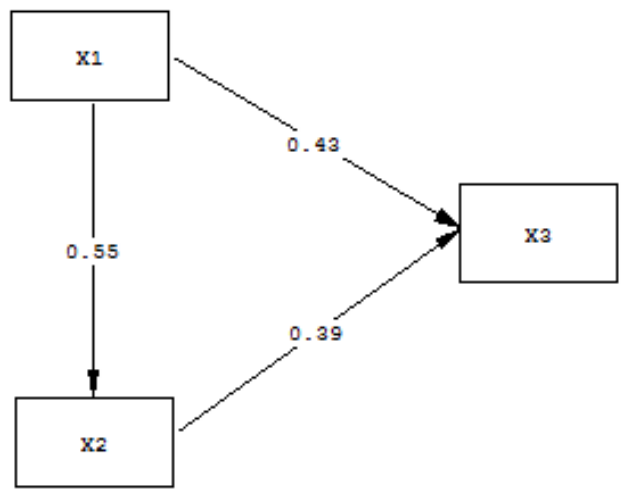

Gambar 1. Path analysis

Hasil analisis jalur menunjukkan bahwa Gaya Kepemimpinan Kepala Sekolah dapat berpengaruh langsung ke Komitmen Kerja dan dapat juga berpengaruh tidak langsung yaitu dari Gaya Kepemimpinan Kepala Sekolah ke Kecerdasan Spritual Guru lalu ke Komitmen Kerja. 


\section{KESIMPULAN}

Berdasarkan hasil korelasi antara $X_{1}, X_{2}$ dan $X_{3}$ tersebut di atas didapat $r_{x 1 \times 3}=0,641, r_{x 2 \times 3}=0,624$ dan $r_{x 1 \times 2}$ $=0,548$, langkah selanjutnya mencari analisis jalur (path analysis) didapat $\mathrm{p}_{21}=0,55, \mathrm{p}_{31}=0,43$ dan $\mathrm{p}_{32}=$ 0,39 di atas 0,05 yang berarti path analysisnya signifikan.

\section{DAFTAR PUSTAKA}

Arifin, Z. 2012 .Penelitan Pendidikan: Metode dan Paradigma Baru. Bandung : Pt. Remaja Rosdakarya.

Arikunto, Suharsimi. 2006. Prosedur Penelitian Suatu Pendekatan Praktik. Jakarta: Rineka Cipta.

Arikunto, Suharsimi. 2007. Dasar-Dasar Evaluasi Pendidikan. Jakarta : Bumi Aksara

Campbell, L, Campbell, B. \& Dickinson, D. 2002. Metode baru melesatkan Kecerdasan. Inisiasi press.

Chairunisa, C. \& Pudjosumedi,. Manajemen Pendidikan . 2012 . Jakarta : UHAMKA Press.

Chatib, M. \& Said, A. 2012. Sekolah Anak-anak Juara Berbasis Kecerdasan Jamak dan Pendidikan Berkeadilan. Bandung : Penerbit Kaifa.

Cooper, R.K \& Shawaf, A. 1999. Executive EQ: Kecerdasan emosional dan organisasi, terjemahan Gramedia. Jakarta: PT. Gramedia Pustaka Utama.

E.Mulyasa. 2009. Manajemen Berbasis Sekolah. Bandung: Remaja Rosdakarya.

Goleman, D. 2000. Kecerdasan Emosi untuk mencapai puncak prestasi, terjemahan Alex Tri Kantjono Widodo, Jakarta : PT. Gramedia.

Gordon, D. 2004. Success Tidhits. Terjemahan Bhuana Ilmu populer. Jakarta : Pt. Bhuana Ilmu Populer.

Husdarta, H.J.S. 2009. Manajemen Pendidikan Jasmani. Bandung: Alfabeta.

Martin A. D . 2003. Emotional Quality Management Refleks. Jakarta: Agra.

Pudjosumedi . Organisasi dan Kepemimpinan . Jakarta : Uhamka Press.

Sugiyono. 2008. Metode Penelitian Pendidikan Pendekatan Kuantitatif, Kualitatif, dan R \& D, Bandung : Alfabeta.

Sopiah. 2008. Perilaku Organisasional, Yogyakarta : Andi.

Syahrial Yusuf. 2011. SEQ (Spiritual Entrepreneurship Quoetient) Kiat Islami Meraib Sukses Sebagai Pengusaha. Dunia Bahagia, Akbirat Surga. Jakarta : Penerbit Lentera Ilmu Cendekia.

Kamus Besar Bahasa Indonesia. Edisi Ke Tiga Departemen Pendidikan Nasional. 2002. Balai Pustaka.

Kumpikaite, V. (2009). Attitude of spirituality: Pilot from Lithuania. The business Review, Cambridge, 13 (1), 271-278.

Koontz, H. \& Weihrich, H. 1990. Essensials of Management. New York : Mcgraw Hill Publishing.

Kolodinsky, R.W., Giacalone, R. A. \& Jurkiewicz, C. L. (2008). Workplace Values and outcomes; exploring Personal, Organizational, and interactive Workplace Spirituality.Journal of Business ethics. 81 (465-480). Di peroleh 11 november 2009 dari ABI/Inform Global.

L.N. Jewell \& Siegall Marc. 1998. Psikologi Industri/ Organisasi Modern. . Edisi 2. Jakarta : Penerbit Arcan.

Mathis and Jakson. 2000. Human Resources Management. New Jersey : Pretice Hill.

Musbikin, I. 2010. Guru yang Menakjuban. Yogyakarta: penerbit Buku Biru.

M. Yaniyullah Delta Auliya. 2005. Melejitkan Kecerdasan Hati \& Otak. Menurut Petunjuk Alquran dan Neurologi. Jakarta : Rajagrafindo Persada. 
Panggabean, M.S. 2002. Manajemen Sumber Daya Manusia. Jakarta. Ghalia Indonesia

Qomar, M. 2007. Manajemen Pendidikan Islam. Strategi baru Pengelolaan Lembaga Pendidikan Islam. Jakarta : Penerbit Erlangga.

Rivai, V. \& Mulyadi, M. 2011. "Kepemimpinandan Perilaku Organisasi”. Jakarta.

Robbins SP, 2001. Perilaku Organisasi : Konsep, Kontroversi, dan Aplikasi. Jilid 1. Edisi Delapan. Edisi bahasa Indonesia, Pearson Asia Education, Pte, Ltd. Jakarta: PT. Prenhallindo.

Sugiyono. 2008. Metode Penelitian Pendidikan Pendekatan Kuantitatif, Kualitatif, dam R \& D, Bandung : Alfabeta.

Sulastami, R. \& Mahdi, E.M. 2006. Universal Inteligence, Tonggak Kecerdasan untuk Menciptakan dan Menghadapi Perbedaan.Jakarta: Pt. Gramedia. Pustaka Utama.

Supriyanto, T. 2009. Humanitas Spiritual Dalam Pendidikan. : UIN Malang Press.

Sjabadhyani, at all 2001. Pengembangan Kualitas SDM dari Perspektif PIO, Bagian Psikologi Industri dan organisasi, fakultas Psikologi Universitas Indonesia, Depok.

Tasmara, T. 2002. Membudayakan Etos Kerja Islami . Jakarta : Gema Insani.

Tasmara, T. Kecerdasan Ruhaniyah. Jakarta : Gema Insani Pres.

Thoha, M. 2011. Perilaku Organisasi Konsep Dasar dan Aplikasinya. Jakarta : Rajawali press.

.Wahjosumidjo. 2002. Kepemimpinan Kepala Sekolah Tinjuan Teoritik dan Permasalahannya. Jakarta : Rajawali Pers.

Wirawan. 2002. Kapita Selekta. Teori Kepemimpinan. Pengantar Untuk Praktek dan Penilaian. Jilid 2. Jakarta : Uhamka Press dan Yayasan Bangun Indonesia.

Zohar, D. \& Marshall, I. 2001. SQ. Memanfaatkan Kecerdasan Spiritual Dalam Berpikir Integralistik dan Holistik untuk memahami kehidupan. Mizan. 